\title{
Impact of Macroeconomic Variables on Islamic Banks Profitability
}

\author{
Qaisar Ali* \\ Faculty of Islamic Economics and Finance (FEKIM), \\ Universiti Islam Sultan Sharif Ali (UNISSA), \\ Bandar Seri Begawan, Brunei. \\ Email: aliqaisar21@gmail.com \\ *Corresponding author

\section{Selamah Maamor} \\ Islamic Business School (IBS), \\ Universiti Utara Malaysia (UUM), \\ Sintok, Kedah Darulaman, Malaysia.

\section{Hakimah Yaacob} \\ Faculty of Islamic Economics and Finance (FEKIM), \\ Universiti Islam Sultan Sharif Ali (UNISSA), \\ Bandar Seri Begawan, Brunei.

\section{Muhammad Usman Tariq Gill} \\ Faculty of Islamic Economics and Finance (FEKIM), \\ Universiti Islam Sultan Sharif Ali (UNISSA), \\ Bandar Seri Begawan, Brunei
}

Received Feb, 2018; Accepted May, 2018

\begin{abstract}
The main objective of this study is to investigate the impact of macroeconomic variables on Islamic banks' profitability in Brunei. The sample includes Bank Islam Brunei Darussalam (BIBD) from 2012 to 2016. Profitability was measured by Return on Assets (ROA) and Return on Equity (ROE) while macroeconomic variables included were GDP growth rate, inflation, interest rate, exchange rate, oil prices, competition, and money supply. Data was obtained from DEPD, AMBD, and IMF annual reports. The fixed effects panel regression technique was adopted to measure the impact of each variable on Islamic banks' profitability using Stata 15. The findings revealed that GDP growth rate, inflation, exchange rate, oil prices and money supply have a significant and a positive impact on profitability. While oil prices, GDP and inflation are the most significant variables, exchange rate and money supply are the least significant determinants of profitability. The study therefore recommends the regulators and policy makers to discover alternative ways to rejuvenate the economic and the financial system. Islamic bankers may revamp their marketing strategies to reduce the impact of macroeconomic variables. This study has vigorously contributed to the existing literature of Islamic banks' profitability, in the context of a single country analysis, particularly in Brunei.
\end{abstract}

Keywords: Islamic banks; Brunei; Profitability; Macroeconomic Variables; Panel Data Analysis

Type: Research paper

This work is licensed under a Creative Commons Attribution 4.0 International License.

DOI: 10.51325/ijbeg.v1i2.14

\section{Introduction}

Islamic finance plays a leading role in Brunei's banking industry by holding the total assets of BND9.5 billion and deposits of BND7.34 billion which accounts for 59 per cent 
of total market share in the year 2017 (BIBD annual report 2016). The first Islamic bank in Brunei Darussalam was established in 1992 and was named Tabung Amanah Islam (TAIB) (Shahid and Kain, 2001). Brunei has a dual banking system, conventional and Islamic banking operates side by side to cater the financial needs of its versatile multiracial community. Currently, there are two Islamic and six conventional banks in Brunei. Bank Islam Brunei Darussalam (BIBD) is a fully fledged Islamic bank whereas; TAIB partially functions as a retail bank.

Islamic banking is an organised and discrete banking system which operates under predominant Shariah laws. Islamic banking comprised of two fundamental instruments of risk and returns sharing. Shahinpoor (2009) stated that Islamic banking principles suggest that the money should exclusively be manipulated for the exchange of goods and services. Islamic banking is strictly prohibited to use the money for any illegal activity such as interest (riba), gambling (maisir) and speculative trading (gharar). The objective to establish business is to gain profit; therefore, profitability is a fundamental goal of any business entity. Profitability is defined as a circumstances resulting in financial gain or profit through the exchange of potential risk. In the absence of sufficient profitability corporates do not manage to survive in the long run. Therefore, to ensure organizational sustainable existence it is mandatory to measure present and past profitability and subsequently forecast future profitability (Alareeni, 2018; Husain et al, 2015).

Similarly, Profitability is a significant component of banking world as profitability contributes to sustain destructive macroeconomic financial tremors through absorbing and financially contributing in stabilizing the financial system. Based on these characteristics of profitability, it is contemporary to examine and analyse the determinants impacting the profitability of banks. Islamic banking is not limited to generate the profitable outcome for its owners; it also aims to generate a satisfactory financial benefit for the depositors (Masood and Ashraf, 2012). However, macroeconomic factors are beyond the control of banks and in certain circumstances Islamic banking is unable to produce sufficient financial outcome for its customers. Understanding the influence of macroeconomic factors is significant from customers' perspective to provide an estimation of expected profits. This study will enable the Islamic bank customers to understand, analyse and examine the external factors influencing Islamic banks profitability.

The relationship between profitability and banking industry is substantially significant due to the dependence of country's economy on sound and steady banking sector (Albertazzi and Gambacorta, 2009). It is essential to analyse the determinants of profitability in banking sector due to country's economic system dependence on the financial system. The banks' profitability is significant at both micro and macro stages of the economy as the increase in banking sector shares lifts the overall financial system. A steady micro and macroeconomic banking sector indicate the economic growth of a country. At the micro level, sound profits signify the crucial state of callous resources and indicate funds accessibility for a financial institution. 
The achievement of a profitable condition is not merely a choice to ensure financial gains but also a predictability of flourish in banking world to survive in the presence of fierce competition which has currently mounted in financial markets. As stated above a profitable financial institution at micro level represents the availability of resources and funds, however, the macro factors of gross domestic product (GDP), interest rate, inflation, money supply, competition and exchange rate may result in lack of resources and funds (Aburime, 2009). The empirically surveyed literature appears to be lacking to explain the impact of macroeconomic variables on Islamic banks profitability especially in the context of Brunei Darussalam.

Consequently, the present study aims to understand, analyse and examine the impact of macroeconomic variables on the profitability of Islamic banks in Brunei. This research further aims to identify the most significant macroeconomic variable for Islamic banks impacting Islamic banks profitability and the broader objectives of this research include assisting managers and policy makers to improve banks' performance by minimizing the impact of macroeconomic variables.

The rest of paper is arranged as follows; section 2 empirically outlines literature review. Section 3 describes the variables and methodology deployed in this study. Section 4 illustrates the findings and discussion of the study and the section 5 concludes this research.

\section{Literature review}

Yousafi (2016) suggested that profitability variable characterized by two alternate methods: profits to assets ratio, return on assets (ROA) and profits to equity ratio, return on equity (ROE). Whereas, ROA indicates bank's ability to generate profits from its assets and ROE signifies return to shareholders on their equity which is equal to ROA times the $\mathrm{t}$ Bank-specific profitability determinants. Banks profitability is influenced by two variables; micro and macro variables. Micro variables such as bank size, capitalization, liquidity, asset quality, capital ratios and collateral security are controlled variables whereas macro variables such as GDP, interest rate, inflation, exchange rates, money supply, competition and hydrocarbons prices are perceived to be beyond the control of financial institutions (Nahar and Sarker, 2016).

There are a number of studies exist in literature analysing the impact of banks' internal variables and characteristics on Islamic banks profitability (Asutay and Izhar, 2007; Teng, 2012; Wasiuzzaman and Gunasegavan, 2013). To the best of researcher's knowledge, the literature contains a handful studies on the impact of macroeconomic variables and does not contain any formal study measuring the impact of macroeconomic variables on Brunei's Islamic banks' profitability. Hence, this study focuses to understand and analyse the impact of below outlined variables on the profitability of Bruneian Islamic banks. 


\subsection{GDP Growth Rate}

The gross domestic product is considered as one of the most significant macroeconomic variables to represent profitability. Noor and Hayati (2012) investigated the efficiency of 78 Islamic banks in 25 countries and revealed that GDP along with other macroeconomic variables positively impact Islamic banks efficiency. Yousafi (2016) analysed the impact of macroeconomic and structural variables on Jordanian Islamic banks and revealed that GDP has a positive impact on Islamic banks performance. A versatile study conducted by Alharbi (2017) analysed the impact of GDP on the profitability of Islamic banks around the globe and found that profitability is positively affected by GDP. Conforming to the findings of past studies and variance in the scholars' opinion, present study aims to investigate the effect of GDP growth rate on Islamic banks' profitability postulating following hypothesis;

H1: There is a significant positive relationship between GDP growth rate and Islamic banks' profitability.

\subsection{Inflation}

The literature has profoundly discussed the significance of inflation especially its relationship with banks performance. Inflation not only impacts corporates' pricing but also has significant influence on bank customers and financial resources. The higher inflation rate drives corporates to increase the prices of their products as it facilitates corporates to avoid suffering a drop in demand of their output (Driver and Windram 2007). The study of Izhar and Asutay (2007) revealed that the impact of inflation on bank's profitability was first described by Revell (1980), who found that inflation is the most significant factor in causing disparities in banks' profitability. Wasiuzzaman and Ahmed Tarmizi (2010), Bashir (2003), Athanasoglou et al (2005), Vong and Chang (2006), Kunt and Huizinga (2000) and Haron (2004) studies found that inflation positively impacts Islamic banks profitability. However, Sriari (2009) and Naceur (2003) denied the existence of any significant relationship between Islamic banks' profitability and inflation. Pertaining to the findings of past studies and variance in the scholars' opinion, present study aims to investigate the effect of inflation on Islamic banks' profitability postulating following hypothesis;

H2: There is a significant positive relationship between inflation and Islamic banks' profitability.

\subsection{Interest Rate}

The amount/rate charged by the lenders as a compensation for the loss of assets or capital use is known as the interest rate. Interest rate is the most significant factor affecting the demand and supply of bank credit. Bashir (2003) studied the impact of bank characteristics on the overall performance of Islamic banks and found that favourable macroeconomic conditions such as lower interest rate increases Islamic banks profitability. Kader and Leong (2009) analysed the impact of interest rate on Islamic and conventional banks financing in Malaysia and found that interest rate is positively 
associated with Islamic banks credit but negatively related to the conventional bank financing. Similarly, Adebola et al (2011) found that interest rate negatively impacts on Islamic banks financing in Malaysia. Anber and Alper (2011) studied the impact of bank specific and macroeconomic variables on Turkish Islamic banks and found that noninterest income has a positive and significant impact on profitability. Nahar and Sarker (2016) in a cross country analysis found that Islamic banks financing is positively affected by the interest rate. Habib and Islam (2017) studied the impact of macroeconomic factors on Islamic banks stock share and found that interest rate significantly influences the stock market. Based on the findings of past studies and variance in the scholars' opinion, present study aims to investigate the effect of interest rate on Islamic banks' profitability postulating following hypothesis;

H3: There is a significant negative relationship between interest rate and Islamic banks' profitability.

\subsection{Exchange Rate}

Yang and Zeng (2014) defined that "the exchange rate measures the relative price of non-tradable goods in terms of tradable goods". Iriani and Yuliadi (2015) studied the impact of macro variables on non-performance financing of Islamic banks in Indonesia and revealed that exchange rate positively impacts the nonperforming financing. Whereas, Nahar and Sarker (2016) study contradicted these findings and found that exchange rate negatively impacts the financing capability of Islamic banks. Javaid and Alalawi (2017) revealed that exchange rate along with other macroeconomic variables is significant in determining the profitability of Saudi Arabian banks. Similarly, Habib and Islam (2017) found that Islamic banks stock market significantly influences due to interest and exchange rate in India. Based on the findings of past studies and variance in the scholars' opinion, present study aims to investigate the effect of exchange rate on Islamic banks' profitability postulating following hypothesis;

H4: There is a significant positive relationship between exchange rate and Islamic banks profitability.

\subsection{Oil prices}

Oil is the prominent source of revenue for Middle Eastern and North African (MENA) countries and considered as the tipping points of Islamic banks growth in Gulf Cooperation Council (GCC) (Alqahatani, 2017). The countries highly dependent on oil and gas are facing further challenges in economic growth as the oil and gas prices are expected to further fall 70 per cent since mid- 2014 (Standard and Poor's, 2016). Brunei is no exception to it as the fall in oil and gas prices will engender challenges in economic growth since $97 \%$ of its economy is dependent on oil and gas exports (Ali and Swee, 2014). The shrink in economic growth will result in less volatile market, which may minimise Islamic banks profitability. Said (2015) analyzed the influence of oil prices on Islamic banks efficiency and revealed that fluctuations in oil prices do not have a direct influence on Islamic banks efficiency in MENA. The impact of fluctuations in oil prices on Islamic banks' profitability is determined deploying following hypothesis. 
H5: There is a significant positive relationship between oil prices and Islamic banks profitability.

\subsection{Competition}

Competition is described as a significant determinant of bank's profitability. According to the traditional approach, the impact of a new entrant on the profitability is difficult to describe or measure. Heggested and Mingo (1976) revealed that the level of monopoly may influence the competition; the higher monopoly level depicts greater profitability as it enables corporates to gain a control over prices and services regulation. Whalen (1988) findings revealed that the entry of new entrants will not impact the profitability of existing banks when the banking industry is in a competitive state. The following hypothesis analyses the impact of competition on profitability.

H6; There is a significant positive relationship between competition and Islamic banks profitability.

\subsection{Money Supply}

Bourke (1989) determined the effect of money supply and profitability through the annual growth of money supply as a proxy for growth in the market and found the existence of a positive relationship between market expansion and banks' profitability. The findings of Haron and Azmi (2004) were also consistent with Bourke (1989) study as their findings confirmed the positive relationship between money supply and Islamic banks profit. Iriani and Yuliadi (2015) found that money supply along with other macroeconomic variables significantly impact the profitability of non-performing financing of Islamic banks in Indonesia. Arif and Rosly (2011) found that Islamic banks practices are to intensify credit and operate within fractional policies of the banking system which allow them to generate deposits and money supply. Consequently, tightening or relaxation of the money supply by the central bank may affect the profitability of Islamic banks. Pertaining to the literature review, this study aims to analyse the impact of money supply on Islamic banks' profitability postulating following hypothesis;

H7: There is a significant positive relationship between money supply and Islamic banks profitability.

\section{Methodology}

\subsection{Data}

To achieve the objectives of this study the time series data from the year 2012 to 2016 was collected from multiple sources. In this study, one Islamic bank (BIBD) is selected, as it is the only fully fledged Islamic bank in Brunei and TAIB was left out, as its functions are limited. The data on ROA and ROE was obtained from BIBD's and Authoriti Monetari Brunei Darussalam (AMBD) annual reports. AMBD is the regulatory authority and consistently updates the financial reports and contain the relative financial information of the financial institutions in Brunei. The GDP, Inflation, interest rate, 
exchange rate, oil prices, competition, and money supply data was collected from the yearly reports of Brunei's statistical department (Department of Economic Planning and Development, DEPD) and International Monetary Fund (IMF) country reports.

The study deployed panel regression techniques to analyse the macroeconomic determinants of Islamic banks' profitability. Panel data techniques have advantages in providing explanatory data, which has an ability to provide cross sectional information. Panel data describes variance in individual variables over the specific periods, which assist to record dynamic adjustment. Overall, panel model simultaneously helps to identify the variances in the characteristics of a variable. Another crucial justification to deploy panel regression model is that it provides a degree of freedom and efficiency, which permits to study the impact of macroeconomic variables on the developments in the financial industry. This study adopted fixed effects panel regression model as the other technique, random effects estimation requires various cross sections to be greater than coefficients' for between estimators for an estimate of random effect innovation.

\subsection{Measurement of Variables}

Profitability is the dependent variable in this study; it is measured by two dummy variables of ROA and ROE.

\subsection{Return on Assets (ROA)}

ROA indicates the capacity of a corporate to attain deposits at minimal cost and generate sufficient profits through investment. ROA ratio measures the generation of net income on per dollar assets. A higher ROA ratio represents higher profitability of a bank (Kumbirai and Webb, 2010). ROA is widely used as a dummy variable to measure banks' profitability. Peterson and Schoeman (2008) found that ROA ratio is one of the most significant tools to indicate the operational efficiency of a bank.

\subsection{Return on Equity (ROE)}

ROE represents the rate of return to shareholders on each dollar of equity invested in the bank (Kumbirai and Webb, 2010). It is a basic tool to indicate a bank's potential growth and profitability. ROA is calculated by dividing net profit after tax by total equity, whereas, total equity is the sum of total capital and reserves (Siraj and Pillai, 2012). Hence, a higher ratio represents a better use of capital.

\subsection{Model Specification}

To determine the impact of macroeconomic variables on Islamic banks profitability following regression equation is adopted.

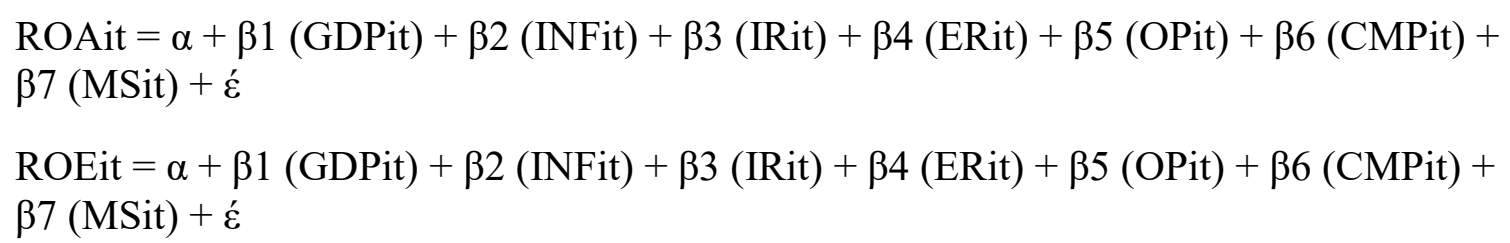


Whereas, ROA and ROE in above equations represent return over assets and return over equity, i refers to individual bank; t represents year. IR, GDP, INF, ER, OP, CMP, and MS represent macroeconomic variables of interest rate, gross domestic product, inflation, exchange rate, oil prices, competition and money supply and $\dot{\varepsilon}$ represents error term.

\section{Empirical Findings and Discussion}

\subsection{Statistical Findings}

The statistical findings of the variables deployed in this are presented below in table 1 .

Table 1: Statistical detail of the variables

\begin{tabular}{|l|c|c|c|c|c|}
\hline Variables & 2012 & 2013 & 2014 & 2015 & 2016 \\
\hline ROA (\%) & 2.20 & 1.40 & 1.50 & 1.80 & 1.5 \\
\hline ROE (\%) & 10.20 & 5.60 & 7.50 & 8.70 & 9.8 \\
\hline GDP (BND/year) & $59,535.5$ & $55,733.1$ & $52,748.0$ & $42,684.3$ & $37,257.0$ \\
\hline INF & $+0.2 \%$ & $+0.4 \%$ & $-0.2 \%$ & $+0.4 \%$ & $+0.7 \%$ \\
\hline IR & 5.50 & 5.50 & 5.50 & 5.50 & 5.50 \\
\hline ER (1USD to 1BND) & 1.22 & 1.27 & 1.32 & 1.41 & 1.38 \\
\hline OP (BND) & $16.43 \mathrm{~b}$ & $14.95 \mathrm{~b}$ & $13.93 \mathrm{~b}$ & $10.11 \mathrm{~b}$ & $8.2 \mathrm{~b}$ \\
\hline CMP & 0.00 & 0.00 & 0.00 & 0.00 & 0.00 \\
\hline MS (BND) & $13.96 \mathrm{~b}$ & $14.2 \mathrm{~b}$ & $14.62 \mathrm{~b}$ & $14.36 \mathrm{~b}$ & $14.58 \mathrm{~b}$ \\
\hline
\end{tabular}

Source: DEPD, $A M B D, I M F$

Table 1 contains the statistics of ROA, ROE and macroeconomic variables deployed in this study. The 1st and 2nd rows of table 1 contain statistics of ROA before taxes and ROE after taxes. Net profit growth was BND97.9m in the year 2012 with an annual increase of $42.8 \%, 25 \%$ and $34.8 \%$ in ROA and ROE and net profit. However, it substantially dropped to BND59.7m in the year 2013 with an annual reduction of $39.01 \%$, $36.35 \%$ and $45.09 \%$ in net profit, ROA and ROE. It revived in the following year of 2014 and became BND83.9m with 40.53\%, 7.14\%, 33.92\% increase in net profit, ROA and ROE. The net profit continued growing in the years 2015 and 2016 to BND100.6m and BND122.1m with annual growth of $19.90 \%$ and $21.37 \%$. ROA increased $20 \%$ in the year 2015 and decreased $16.6 \%$ in the year 2016. ROE increased $16 \%$ and $12.64 \%$ in the years 2015 and 2016.

The 3rd row depicts the per capita growth rate of gross domestic product (GDP) in Brunei. The row depicts that per capita GDP increased $0.9 \%$ in the year 2012 and it decreased $6.3 \%, 5.3 \%, 19.07 \%$, and $12.7 \%$ in the subsequent years of 2013, 2014, 2015 and 2016. The 4th row represents inflation rate, the inflation rate increased $0.2 \%$ to $0.4 \%$ in in the years 2012 and 2013. However, it decreased $0.2 \%$ in the year 2014 and increased again by $0.4 \%$ in the year 2015 and continued increasing by $0.7 \%$ until the end of year 2016.

It can be noted from the 5th row that banks' interest rate was constant at 5.50 per cent from the year 2012 to 2016. The 6th row represents Brunei Dollar's exchange rate 
compared to United States Dollar, the row indicates that exchange rate dropped in the year 2012 by $6.1 \%$. However, the exchange rate continued improving by $4.09 \%, 3.93 \%$ and $6.81 \%$ in the years 2013, 2014 and 2015 and eventually decreased by $2.12 \%$ in the year 2016. The 7th row of the table indicates the oil prices measured in billion Brunei Dollars, the oil prices increased by $0.02 \%$ in the year 2012 which considerably dropped by $9 \%$ in the subsequent year 2013. The prices continued falling in the following years 2014, 2015 and 2016 by $6.84 \%, 27.355$ and $18.13 \%$ respectively. The 8 th row of table 1 shows the competition level among Islamic banks in Brunei. The absence of any new Islamic bank entrant resulted in zero competition for BIBD from the year 2012 to the year 2016. The last row of table 1 shows the money supply, it grew by $0.9 \%, 1.7 \%$ and $2.9 \%$ in the years 2012, 2013 and 2014. The money supply decreased by $1.7 \%$ in the year 2015 and increased again by $1.5 \%$ in the year 2016 .

\subsection{Descriptive Findings}

The descriptive statistics of dependent and independent variables of this study are presented in table 2 .

Table 2: Descriptive analysis

\begin{tabular}{|l|l|l|l|l|l|}
\hline Variables & Mean & Median & Maximum & Minimum & S.D \\
\hline ROA & 1.680 & 1.500 & 2.2 & 1.4 & 0.3271 \\
\hline ROE & 8.360 & 8.700 & 10.2 & 5.6 & 1.8663 \\
\hline GDP & 49611.6 & 52848.1 & 59535.5 & 37257.0 & 9314.7 \\
\hline INF & 0.380 & 0.400 & 0.7 & 0.2 & 0.2049 \\
\hline IR & 5.500 & 5.500 & 5.5 & 5.5 & 0.0000 \\
\hline ER & 1.32 & 1.32 & 1.41 & 1.22 & 0.07778 \\
\hline OP & 12.448 & 13.930 & 16.4 & 8.2 & 2.7844 \\
\hline CMP & 0.00 & 0.00 & 0 & 0 & 0.000 \\
\hline MS & 14.344 & 14.360 & 14.623 & 13.961 & 0.2740 \\
\hline
\end{tabular}

The table 2 shows that dependent variables of ROA and ROE mean are 1.680 and 8.360 , the standard deviation values of these variables are .3271 and 1.8663 . Pertaining to independent variables GDP, Inflation, interest rate, exchange rate, oil prices, competition and money supply have means of 49611.6, 0.380, 5.500, 1.32, 12.448 and 14.344 and standard deviation errors are 9314.7076, .2049, .0000, .07778, .0000 and .2740 respectively.

\subsection{Panel Regression Analysis}

The results of panel regression analysis are presented in table 3 and 4.

Table 3: Panel regression analysis: ROA on selected variables

\begin{tabular}{|l|l|l|l|l|l|}
\hline Dependent variable: ROA & & & & & \\
\hline Independent Variables & Coefficient & S.E & t-statistics & Prob. & \\
\hline GDP & 1.078447 & 1.007411 & 5.842420 & 0.000 & $* * *$ \\
\hline INF & 1.015684 & 1.193860 & 1.824011 & 0.000 & $* * *$ \\
\hline
\end{tabular}




\begin{tabular}{|l|l|l|l|l|l|}
\hline ER & 1.060315 & 1.072063 & 1.747652 & 0.0211 & $* * *$ \\
\hline OP & 1.015138 & 1.008087 & 1.852777 & 0.0043 & $* * *$ \\
\hline MS (OEDR) & 1.074354 & 1.01421 & 2.66524 & 0.000 & $* * *$ \\
\hline \multicolumn{5}{|c|}{ Effects Specification } \\
\hline $\begin{array}{l}\text { Cross section fixed (dummy variables) } \\
\text { R square }\end{array} \quad 0.744511$ & Mean dependent Var. & 1.680 & \\
\hline $\begin{array}{l}\text { Adjusted R square } \\
\text { S.E of regression }\end{array}$ & 0.72554 & S.D. dependent Var. & .3271 & \\
\hline $\begin{array}{l}\text { Sum squared residual } \\
\text { Long likelihood }\end{array}$ & 0.062552 & Akaike info criterion & -2.22997 & \\
\hline $\begin{array}{l}\text { F-statistics } \\
\text { Prob. (F-statistics) }\end{array}$ & 0.594423 & Schwarz criterion & -2.68928 & \\
& 149.2205 & Hannan-Quinn criteria & -2.87770 & \\
\hline
\end{tabular}

$* * *$ represents significance at $1 \%, * *$ at $5 \%$ and $* 10 \%$ respectively

Table 4: Panel regression analysis: ROE on selected variables

\begin{tabular}{|l|l|l|l|l|l|}
\hline Dependent variable: ROE & & & & & \\
\hline Independent Variables & Coefficient & S.E & t-statistics & Prob. & \\
\hline GDP & 5.168424 & 4.797411 & 5.82450 & 0.000 & $* * *$ \\
\hline INF & 5.934571 & 5.283420 & 4.826099 & 0.000 & $* * *$ \\
\hline ER & 5.060315 & 5.072063 & 5.739872 & 0.0211 & $* *$ \\
\hline OP & 5.015138 & 5.008087 & 4.846725 & 0.0043 & $* * *$ \\
\hline MS & 5.074354 & 5.01421 & 2.627456 & 0.000 & $* * *$ \\
\hline \multicolumn{7}{|l|}{ Effects Specification } & \\
\hline Cross section fixed (dummy variables) \\
R square & 0.80409 & Mean dependent Var. & 8.360 & \\
\hline Adjusted R square & 0.79554 & S.D. dependent Var. & 1.8663 & \\
S.E of regression & 0.261442 & Akaike info criterion & -2.43567 & \\
\hline Sum squared residual & 0.593499 & Schwarz criterion & -5.50354 & \\
Long likelihood & 148.2351 & Hannan-Quinn criteria & -5.87770 & \\
\hline F-statistics & 80.0045 & Durbin-Watson stat & 5.235685 & \\
Prob. (F-statistics) & 0.00000 & & & \\
\hline
\end{tabular}

***represents significance at $1 \%, * *$ at $5 \%$ and $* 10 \%$ respectively

The panel regression analysis results presented in table 3 and 4 depicted that values of R-square are equal to $74.45 \%(.7445) 80.40 \%$ (.8040) which proved that the proposed model, to predict Islamic banks' profitability is the best fit as R-square values are greater than threshold values of $60 \%$ (.60). Pearson correlation test was conducted to detect the problem of multicollinearity in the proposed model as the variables of interest rate (IR) and competition (CMP) was found constant and were dropped from further analysis. The final model measured the impact of GDP growth rate, inflation, exchange rate, oil prices and money supply on profitability. The F-statistics were found significant at $1 \%$ level in both models which proved that all independent variables (GDP growth rate, inflation, exchange rate, oil prices and money supply) collectively influence the dependent variables. 
The coefficient and $t$ values of GDP presented in table 3 and 4 shows that it is significant and positively influence the profitability. It implies that Brunei's Islamic banks may substantially promote GDP growth rate and assist to diversify Bruneian economy provided these banks are considered profitable. This result is parallel with the findings of Noor and Hayati (2012), Yousafi (2016) and Alharabi (2017), these studies found a significantly positive relationship between Islamic banks' profitability and GDP growth rate. It has also verified that the first hypothesis of this study was accepted. Turning to inflation (INF) rate coefficient and $t$ values, it depicted that inflation rate has a significant positive impact on Islamic banks' profitability. It is inferred that the higher inflation level drive corporates including banks to increase the prices of their products and services to minimise the impact of lack of demand which may considerably reduce the sales and ultimately impact the revenues. A low inflation rate provides flexibility to consumers in purchasing goods and services at lowest prices. This result is consistent with Bashir (2003), Haron (2004) and Vong and Chang (2006), these studies have also found inflation positively impacting Islamic banks' profitability. It verified the existence of a significant positive relationship between inflation and Islamic banks' profitability hence, hypothesis 2 of this study was accepted.

The panel regression results (see table 3 and 4) of exchange rate represent that it is positive and significant suggesting that a higher exchange rate may considerably increase the profitability of Bruneian Islamic banks. These findings are parallel with Javaid and Alalawi (2017) and Habib and Islam (2017), these studies found that exchange rate is significant in determining the profitability and stock prices of Islamic banks. It contradicts Nahar and Sarker (2016) study which revealed that exchange rate has a negative impact on Islamic banks' profitability hence; hypothesis 4 of this study is accepted. The results of oil prices presented in table 3 and 4 revealed that it has a significant positive impact on the profitability. It is inferred that lower oil prices result in lower profit for Islamic banks. It is an alarming condition for the oil dependent countries including Brunei as oil and gas contribute more than $60 \%$ in the national economy (DEPD, 2016). The countries highly rely on the income from oil and gas resources are in dire need of relocation of alternative resources to reduce the shocks of lower oil prices. This finding supports the acceptance of hypothesis 5 of this study.

The coefficient and $t$ values of money supply revealed that it has a significant positive impact on profitability ratios of ROA and ROE. It is submitted that provision of flexible and relaxed policies by AMBD may enable Islamic banks in Brunei to intensify credit and generate deposits which will result in higher profitability. These findings are consistent with Haron and Azmi (2004) and Arif and Rosly (2011), a significant positive relationship was revealed between money supply and profitability it signifies that $H 7$ of this study was also accepted.

\section{Conclusion}

This study has shed a light on macroeconomic determinants affecting the Bruneian Islamic banks' profitability precisely from 2012 to 2016 . The economic system of Brunei 
heavily relies on revenue from oil and gas prices which have significantly dropped in this phase. The secondary data of macroeconomic variables (GDP growth rate, inflation, interest rate, exchange rate, oil prices, competition and money supply) was collected from DEPD, AMBD and IMF annual reports. The fixed effects panel regression technique was adopted for data analysis using Stata 15. During data analysis the variables of interest rate and competition were dropped as these were found constant during the selected study period. The final model focused on analysing the effect of remaining 5 variables on Islamic banks' profitability. The findings delineated that GDP, inflation, exchange rate, oil prices and money supply have a significant positive impact on Islamic banks' profitability. Overall, the findings revealed that oil prices, GDP, inflation, exchange rate and money supply were the most significant macroeconomic determinants of BIBD profitability. The analysis further verified that hypotheses $H 1, H 2, H 4, H 5$, and $H 7$ were accepted whereas, $H 3$ and $H 6$ were rejected.

This study has versatile practical implications for regulators, policy makers and Islamic bankers. The government and regulatory authorities need to discover alternative resources other than hydrocarbons to revitalize its economy and engender profitable financial structure. The managerial team of Islamic banks needs to delineate flexible and profitable pricing strategies during excessive inflation. AMBD may induce surplus money supply so that Islamic banks are able to intensify credit and enhance its profitability through investment.

\section{End Notes:}

For further statistical reading view following pages;

1. Department Of Statistics Department of Economic Planning and Development (DEPD). (2016), "Brunei Darussalam Key indicators". Available at: http://www.depd.gov.bn/DEPD\%20Documents\%20Library/DOS/BDKI/BDKI \%202016.pdf (Accessed on March 20, 2018).

2. Department Of Statistics Department of Economic Planning and Development (DEPD). (2010-2013), “ANNUAL NATIONAL ACCOUNTS (NEW BASE YEAR 2010), 2010 - 2013”. Available at: http://www.depd.gov.bn/DEPD\%20Documents\%20Library/DOS/ANA/ANA\% 20New\%20Base\%20Year.pdf (Accessed on March 20, 2018).

3. AMBD Annual Report. (2012). Available at: http://www.ambd.gov.bn/SiteAssets/Lists/Publications/AllItems/Autoriti\%20M onetari\%20Brunei\%20Darussalam\%20Annual\%20Report\%202012.pdf (Accessed on March 20, 2018).

4. AMBD Annual Report. (2013). Available at: http://www.ambd.gov.bn/SiteAssets/AMBD\%20Annual\%20Report/AMBD\%20 Annual\%20Report\%202103.pdf (Accessed on March 21, 2018).

5. BIBD Annual Report. (2012). Available at: http://www.bibd.com.bn/assets/pdf/media-centre/annualreport/2012\%20Annual\%20Report\%20-\%20English.pdf (Accessed on March 21, 2018).
6. BIBD
Annual
Report.
(2013).
Available
at: http://www.bibd.com.bn/assets/pdf/media-centre/annual- 
report/2013\%20Annual\%20Report\%20-\%20English.pdf (Accessed on March 21, 2018).

7. BIBD Annual Report. (2014). Available at: http://www.bibd.com.bn/assets/pdf/media-centre/annualreport/2014\%20Annual\%20Report\%20-\%20English.pdf (Accessed on March 21, 2018).

8. BIBD Annual Report. (2015). Available at: http://www.bibd.com.bn/assets/pdf/media-centre/annualreport/2015\%20Annual\%20Report\%20-\%20English.pdf (Accessed on March 22, 2018).

9. BIBD Annual Report. (2016). Available at: http://www.bibd.com.bn/assets/pdf/media-centre/annualreport/2016\%20Annual\%20Report\%20-\%20English.pdf (Accessed on July 10, 2017).

\section{References}

Aburime, U.T. (2009). Impact of political affiliation on bank profitability in Nigeria. African Journal of Accounting, Economics, Finance and Banking Research, 4(4), 61-75.

Adebola, S.S., Yousaf, W.S.W., \& Dahalan, J. (2011). The impact of macroeconomic variables on Islamic banks financing in Malaysia. Research Journal of Finance and Accounting, 2(4), 22-32.

Alareeni, B., \& Alqallaf, H. (2018). Evolving of selected integrated reporting capitals among listed Bahraini banks. International Journal of Business Ethics and Governance, 1(1), 15-36. https://doi.org/10.51325/ijbeg.v1i1.10

Albertazzi, U., \& Gambacorta, L. (2009). Bank profitability and the business cycle. Journal of Financial Stability, 5, 393-409. https://doi.org/10.1016/j.jfs.2008.10.002

Alharbi, A.T. (2017). Determinants of Islamic banks' profitability: International evidence. International Journal of Islamic and Middle Eastern Finance and Management, 10(1), 331-350. https://doi.org/10.1108/IMEFM-12-2015-0161

Ali, A.M. J.A.B., Swee, T.T., \& Lee, Y.C. (2014). Brunei: Islamic banking and finance. In S. Thiagaraja, A. Morgan, A. Tebutt, G. Chan (Eds.), The Islamic Finance Handbook: A Practitioner's Guide to the Global Markets (pp.59-76). John Wiley \& Sons.

Alqahtani, F., Mayes, D.G., \& Brown, K. (2017). Islamic bank efficiency compared to conventional banks during the global crisis in the GCC region. Journal of International Financial Markets Institutions and Money, 51, 58-74. https://doi.org/10.1016/j.intfin.2017.08.010

Anbar, A., \& Alper, D. (2011). Bank specific and macroeconomic determinants of commercial bank profitability: Empirical evidence from Turkey. Business and Economics Research Journal, 2(2), 139-152.

Ariff, M., \& Rosly, S.A. (2011). Islamic banking in Malaysia: Unchartered waters. Asian Economic Policy Review, 6(2), 301-319. https://doi.org/10.1111/j.17483131.2011.01208.x 
Asutay, M., \& Izhar, H. (2007). Estimating the profitability of Islamic banking: Evidence from Bank Muamalat Indonesia. Review of Islamic Economics, 11(2), 17-29.

Athanasoglou, P.P., Brissmis S.N., \& Delis, M.D. (2008). Bank-specific, industry-specific and macroeconomic determinants of bank profitability. Journal of International Financial Markets Institutions and Money, 18(2), 121-136. https://doi.org/10.1016/j.intfin.2006.07.001.

Bashir, A.H.M. (2003). Determinants of profitability in Islamic banks: Some evidence from the Middle East. Islamic Economic Studies, 11(1), 31-57.

Bank Islam Brunei Darussalam (2016). Annual report 2016. https://www.bibd.com.bn/assets/pdf/media-centre/annualreport/2016\%20Annual\%20Report\%20-\%20English.pdf

Bourke, P. (1989). Concentration and other determinants of bank profitability in Europe, North America and Australia. Journal of Banking and Finance, 13, 65-79. https://doi.org/10.1016/0378-4266(89)90020-4

Driver, R., \& Windram, R. (2007). Public attitudes to inflation and interest rates. Bank of England Quarterly Bulletin, 47(2), 208-223.

Habib, M., \& Islam, U.K. (2017). Impact of macroeconomic variables on Islamic stock market returns: Evidence from Nifty 50 Shariah Index. Journal of Commerce and Accounting Research, 6(1), 37-44.

Haron, S. (2004). Determinants of Islamic bank profitability. Global Journal of Finance and Economics, 1(1), 11-33.

Haron, S., \& Azmi, W.N.W. (2004). Profitability determinants of Islamic banks: A cointegration approach. Proceedings of the Islamic Banking Conference, Union Arab Bank, Beirut, Lebanon, 5-7.

Heggested, A.A., \& Mingo, J. J. (1976). Price, non-prices, and concentration in commercial banking. Journal of Money, Credit, and Banking, 8(2), 107- 117. https://doi.org/10.2307/1991923

Husain, A., Affandi S., \& Shukur, N.A (2015). The internal determinants of Islamic banks' profitability in Malaysia. Journal of Basic and Applied Scientific Research, 5(7), 17-21.

Iriani, L.D., \& Yuliadi, I. (2015). The effect of macroeconomic variables on nonperformance financing of Islamic Banks in Indonesia. Economic Journal of Emerging Markets, 7(2), 120-134. https://doi.org/10.20885/ejem.vol7.iss2.art5

Izhar, H., \& Asutay, M. (2007). Estimating the profitability of Islamic banking: Evidence from Bank Muamalat Indonesia. Review of Islamic Economics, 11(2), 17-29.

Javaid, S., \& Alalawi, S. (2017). Performance and profitability of Islamic banks in Saudi Arabia: An empirical analysis. Asian Economic and Financial Review, 8(1), 38-51. https://doi.org/10.18488/journal.aefr.2018.81.38.51

Kader, A.R., \& Leong, Y. (2009). The impact of interest rate changes on Islamic bank financing. International Review of Business Research Papers, 5(3), 189-201.

Kumbirai, M., \& Webb, R. (2010). A financial ratio analysis of commercial bank performance in South Africa. African Review of Economics and Finance, 2(1), 3053. 
Demirguc-Kunt, A., \& Huizinga, H. (2000). Financial structure and bank profitability (Policy Research working Paper Series 2430). The World Bank. https://doi.org/10.1596/1813-9450-2430

Masood, O., \& Ashraf, M. (2012). Bank-specific and macroeconomic profitability determinants of Islamic banks: The case of different countries. Qualitative Research in Financial Markets, 4(2/3), 255-268. https://doi.org/10.1108/17554171211252565

Naceur, S. (2003). The Determinants of the Tunisian Banking Industry Profitability: Panel Evidence (Universite Libre de Tunis Working Papers). https://www.mafhoum.com/press6/174E11.pdf.

Nahar, S., \& Sarker, N. (2016). Are macroeconomic factors substantially influential for Islamic bank financing? Cross-country evidence. Journal of Business and Management, 18(6), 20-27.

Noor, M.K., \& Hayati, N. (2012). Relationship between Islamic banking profitability and determinants of efficiency. Global Business Review, 13(2), 179-200. https://doi.org/10.1177/097215091201300201

Peterson, M.A., \& Schoeman, I. (2008). Modeling of banking profit via return-on-assets and return-on-equity. Proceedings of the World Congress on Engineering, London, $U K, 2,1-6$.

Said, A. (2015). The influence of oil prices on Islamic banking efficiency scores during the financial crisis: Evidence from the MENA area. International Journal of Finance \& Banking Studies, 4(3), 35-43. https://doi.org/10.2139/ssrn.2666096

Shahid, E.M., \& Kain, T.J. (2001). Islamic banking in Brunei Darussalam. International Journal of Social Economy, 3(2), 314-337.

Shahinpoor, N. (2009). The link between Islamic banking and microfinancing. International Journal of Social Economics, 36(10), 996-1007. https://doi.org/10.1108/03068290910984777

Siraj, K.K., \& Pillai, P.S. (2012). Comparative study on performance of Islamic banks and conventional banks in GCC region. Journal of Applied Finance \& Banking, 2(3), 123-161.

Srairi, S.A. (2009). Factors influencing the profitability of conventional and Islamic commercial banks in GCC Countries. Review of Islamic Economics, 13(1), 5-30.

Standard \& Poor Global. (2016). Islamic finance outlook: 2017 Edition. https://www.spratings.com/documents/20184/0/Islamic+Finance+Outlook+2017/5 abbe572-c826-4622-bd13-1aba725281fc.

Teng, K.Y. (2012). The determinants of Islamic banks profitability in Malaysia [Unpublished doctoral dissertation]. Universiti Tunku Abdul Rahman, Malaysia.

Vong, A., \& Chan, H. (2009). Determinants of bank profitability in Macao. Macau Monetary Research Bulletin, 12(6), 93-113.

Wasiuzzaman, S., \& Tarmizi, H. (2010). Profitability of Islamic banks in Malaysia: An empirical analysis. Journal of Islamic Economics, Banking and Finance, 6(4), 5368.

Whalen, G. (1988). Actual competition, potential competition, and bank profitability in rural markets. Economic Review, 24(3), 14-23. 
Yang, B.Z., \& Zeng, T. (2014). A note on the real currency exchange rate: Definitions and implications. Journal of International Business and Economics, 2(4), 45-55. https://doi.org/10.15640/jibe.v2n4a3

Yousfi, I. (2016). The impact of macroeconomic, structural variables and banks' characteristics on Islamic banks performance: Panel evidence from Jordanian banks (2000-2014). El-Bahith Review, 16/2016, 29-42. https://doi.org/10.12816/0034356 